Vol. 1 No. 1 Januari 2022, e-ISSN : 2827-8070 | p-ISSN : 2827-8240

\title{
GAMBARAN KECEMASAN, DEPRESI DAN MEKANISME KOPING PERAWAT MENGHADAPI MASA PANDEMI COVID-19
}

\author{
TUNIK $^{1}$, ELOK YULIDANINGSIH ${ }^{2}$, AWAN HARIYANTO \\ 1,2,3 Program Studi D3 Keperawatan Trenggalek Poltekkes Kemenkes Malang. \\ E-mail : tunik2502@gmail.com
}

\begin{abstract}
ABSTRAK
Coronavirus disease 2019 (COVID-19) adalah penyakit yang disebabkan oleh severe acute respiratory syndrome coronavirus 2 (SARS-CoV-2) dan pertama ditemukan di Wuhan, China Perawat merupakan salah satu tenaga kesehatan yang sangat rentan menerima dampak dari munculnya covid-19. Gangguan psikologis kecemasan sangat mudah dialami oleh perawat dengan berbagai sumber penyebab. Tujuan penelitian ini adalah untuk memberikan gambaran Kecemasan, Depresi dan Mekanisme Koping Perawat di Wilayah Kabupaten Trenggalek Menghadapi Masa Pandemi Covid-19. Desain penelitian ini adalah studi cross sectional. Jumlah responden dalam penelitian ini adalah 60 perawat yang bekerja di RSUD dr.Soedomo Trenggalek dan 8 Puskesmas di wilayah Kabupaten Trenggalek. Partisipan diberikan kuesioner tentang kecemasan dan depresi dengan menggunakan DASS (Depression, Anxiety and Stress Scale),dan kuesioner yang berisi tentang mekanisme koping dalam menghadapi stressor, kemudian hasil penelitian digambarkan secara deskriptif. Hasil penelitian menunjukkan bahwa $25 \%$ perawat mengalami kecemasan ringan-sedang, $10 \%$ perawat mengalami depresi ringansedang dan $13 \%$ perawat mengalami gejala psikologis stress ringan. Mekanisme koping yang digunakan oleh perawat ketika mengalami kecemasan adalah mencari dukungan, melakukan relaksasi, melakukan olahragakecil dan berdoa. Mekanisme koping maladaptif yang digunakan sebagian perawat ketika mengalami kecemasan dan stress antara lain menghindar, menyendiri, menjadi pendiam, menangis, marah dan lain-lain. Berdasarkan hasil penelitian ini, diharapkan layanan kesehatan menyediakan dukungan psikologis atau terapi psikologis pada perawat agar kecemasan atau depresi perawat tidak menyebabkan dampak yang lebih berat.
\end{abstract}

Kata kunci : Perawat Covid-19, Kecemasan, Depresi, Mekanisme Koping

\section{ABSTRACT}

Coronavirus disease 2019 (COVID-19) is a disease caused by severe acute respiratory syndrome coronavirus 2 (SARS-CoV-2) and for the first time found in Wuhan, China. Nurses are one of the health professionals who are very risky to the impact of Covid-19. Anxiety psychological disorder is very commonly experienced by the nurses with various cause predictors. This research aimed to provide description of anxiety, depression, and coping mechanism of nurses during Covid-19 pandemic in Trenggalek. The design of this research was cross-sectional study with the total participants of the research were 60 nurses working at dr. Soedomo Hospital and 8 Community Health Center in Trenggalek. The instrument used in this research were two types of questionnaires regarding with anxiety and depression with DASS (Depression, Anxiety, and stress Scale), and coping mechanism to face the stressors and at last the result of the research was described. The result showed that $25 \%$ of nurses experienced mild to moderate anxiety, $10 \%$ of nurses suffered from mild to moderate depression, and $13 \%$ of nurses suffered from the symptoms of mild stress. Coping mechanism applied by the nurses when they experienced the anxiety was seeking for support, doing relaxation and light exercises and praying. Maladaptive coping mechanism used by the nurses when they experienced anxiety and stress were avoiding, self-isolation, silence, crying, anger, and so forth. According to the result, it was expected that the health service provided psychology and psychological therapy to the nurses in order to prevent further complicated impact.

Key words: Nurses of Covid-19, Anxiety, Depression, Coping Mechanism PENDAHULUAN 
Corona Virus Desease (Covid-19) merupakan virus yang pertama kali muncul di Cina pada akhir tahun 2019. Covid-19 merupakan varian dari virus-virus yang pernah melanda di dunia seperti SARS, flu burung, dan MERS. Saat ini virus ini menyebar ke seluruh penjuru dunia dan menginveksi hampir 5 juta orang, dengan angka kejadian yang terus meningkat dan kasus kematian yang semakin meningkat. Tanda dan gejala umum umum infeksi covid-19 antara lain gejala gangguan pernafasan akut seperti demam, batuk dan sesak nafas dengan masa inkubasi rata-rata 5-6 hari dengan masa inkubasi 14 hari. Pada kasus covid-19 yang berat dapat menyebabkan penumonia, sindrom pernapasan akut gagal ginjal bahkan kematian. Gejala klinis yang nampak adalah demam dan kesulitan bernafas. Sifat dari Covid -19 yang mudah menular menimbulkan dampak yang besar pada semua sistem kehidupan seperti terganggunya sistem kesehatan, perekonomian, aktivitas belajar, ekonomi dan sosial, dan yang paling mengkhawatirkan adalah dampak psikologis kecemasan sampai dengan depresi yang dialami oleh masyarakat secara umum, dan juga oleh tenaga kesehatan yang secara langsung berhadapan dengan penderita covid-19.

Perawat merupakan salah satu tenaga kesehatan yang sangat rentan menerima dampak dari munculnya covid-19. Gangguan psikologis kecemasan sangat mudah dialami oleh perawat dengan berbagai sumber penyebab. Ketidaksiapan perawat dan rumah sakit untuk memberikan perawatan pada penderita covid-19 merupakan salah satu stressor munculnya kecemasan. Meskipun demikian perawat sebagai garda terdepan dalam menerima dan menangani pasien mau tidak mau harus melakukan tanggung jawab tersebut. Stresor lain yang memunculkan kecemasan pada perawat adalah ketersediaan alat pelindung diri (APD) di layanan kesehatan, kebijakan manajemen Rumah Sakit dalam menangani penyakit Covid-19, kepatuhan pasien terhadap protokol yang di tetapkan oleh rumah sakit, kepatuhan penunggu pasien, pasien dan penunggu pasien yang tidak jujur terhadap tenaga kesehatan, kelelahan dalam menjalankan tanggung jawab, kebosanan masyarakat dalam mematuhi protokol kesehatan, peningkatan angka kejadian perawat yang menderita covid, jumlah tenaga kesehatan yang meninggal karena covid-19 menjadi sumber munculnya kecemasan dan depresi bagi perawat yang bekerja baik di Rumah Sakit maupun di Puskesmas.

Covid-19 menyebar dengan cepat ke seluruh dunia, tercatat lebih dari 213 negara yang terkonfirmasi terinfeksi covid-19, dengan jumlah korban yang terinfeksi sampai tanggal 16 mei 2020 sebanyak 4.639.427 orang, meninggal 308.810 orang dan sembuh sebanyak 1.766 .175 orang (http://www.worddometers.info/coronavirus/). Data terbaru tanggal 12 Juli 2020 jumlah korban yang terinfeksi covid-19 di dunia telah mencapai lebih dari 12.500.000 orang. Sementara, di Indonesia, kasus covid-19 pertama muncul pada tanggal 2 Februari 2020 dan sampai tanggal 13 Juli 2020 jumlah korban yang terkonfirmasi positif covid-19 telah mencapai 76.981 orang dengan 3.656 orang meninggal dan 36.689 sembuh. Pada awalnya jakarta merupakan kota dengan jumlah penderita terbanyak yang di ikuti oleh kota-kota lain. Saat ini Jawa Timur merupakan provinsi yang memiliki kasus terbanyak, menurut data dari Satgas Covid-19 Jatim tanggal 13 Juli 2020 jumlah kasus penderita covid-19 mencapai 16.862 orang, dengan rincian jumlah pasien terkonfirmasi positif 16.862, jumlah kasus sembuh 6.858 orang dan kasus meninggal 1.261 orang, sedangkan data tanggal 5 Juli 2020 jumlah perawat yang terkonfirmasi terinfeksi covid-19 di Jawa Timur sebanyak 246 perawat. Jumlah perawat yang meninggal sebanyak 11 orang (kompas TV, tanggal 5 Juli 2020). Kabupaten Trenggalek merupakan salah satu Kabupaten yang memiliki jumlah penderita kasus covid-19 yang terus meningkat setiap hari pada saat tatanan new normal diberlakukan. Pada saat ini jumlah kasus tanggal 13 Juli 2020 di Kabupaten Trenggalek berdasarkan informasi dari gugus tugas penanganan covid-19 Kabupaten Trenggalek adalah sebanyak 42 kasus terkonfrimasi positif covid-19, 22 orang dinyatakan sembuh, 55 orang pasien dalam pengawasan, dan 16 orang meninggal.

Semakin meningkatnya kasus baru menjadi sumber stresor bagi tenaga kesehatan khususnya perawat dalam menjalani tanggung jawabnya di layanan kesehatan. Banyaknya informasi yang tersedia tentang covid-19, yang dapat diakses di berbagai sumber media, 
menyebabkan informasi yang muncul di masyarakat tersebut berpotensi bias dan membingungkan. Munculnya ketakutan, kecemasan, bahkan masyarakat yang terkesan mengabaikan adanya virus menjadi faktor meningkatnya kasus. Selain itu, stigmatisasi dan diskriminasi masyarakat terhadap penderita Covid atau kelompok yang rentan menderita Covid menyebabkan orang-orang menyembunyikan sakitnya supaya tidak didiskriminasi, menyebabkan mereka tidak mencari bantuan kesehatan dengan segera, dan membuat mereka tidak menjalankan perilaku hidup yang sehat. Stigma bukan hanya bagi penderita maupun bagi orang-orang yang beresiko terhadap Covid-19, tetapi pada saat ini banyak kejadian diluar batas kemanusiaan yang menimpa perawat, sebagai dampak munculnya stigma terhadap perawat. Penolakan sosial terhadap perawat, pengusiran perawat, penolakan jenazah perawat dan pengasingan perawat sudah banyak diberitakan di media massa. Perawat sebagai penerima stigma tersebut dapat mengalami peningkatan gejala psikologis dan depresi (Earnshaw, 2020). Fakta-fakta tersebut semakin menambah daftar stresor tenaga kesehatan ketika harus memberikan pelayanan kesehatan baik di Puskesmas sebagai layanan kesehatan yang pertama bagi masyarakat, maupun bagi Rumah sakit sebagai tempat rujukan.

Mekanisme koping yang tepat sangat dibutuhkan oleh tenaga kesehatan dalam menghadapi stresor dan kecemasan di atas. Koping yang adaftif menghasilkan adaptasi yang menetap yang merupakan kebiasaan baru dan perbaikan dari situasi yang lama. Sedangkan koping yang tidak efektif berakhir dengan maladaftif yang dapat merugikan diri sendiri maupun orang lain maupun lingkungan. Mekanisme koping dapat berbeda-beda dari setiap individu dalam menyelesaikan masalah yang dihadapi. Setiap individu dapat menggunakan koping secara bersama dan strategi yang berbeda-beda, hal ini tergantung dari kemampuan dan kondisi individu tersebut.

Di Kabupaten Trenggalek berdasarkan informasi dati tim pendidikan dan penelitian RSUD, pada masa pandmei Covid-19 belum pernah dilakukan studi tentang gambaran kecemasan, depresi maupaun mekanisme koping yang dihadapi oleh perawat. Berdasarkan latar belakang di atas perlu peneliti berminat untuk melakukan penelitian dengan tema "Gambaran Kecemasan, Depresi dan Mekanisme Koping Perawat di Wilayah Kabupaten Trenggalek Menghadapi Masa Pandemi Covid-19"

\section{METODE PENELITIAN}

Penelitian ini merupakan studi descriptive kualitatif dengan pendekatan cross sectional. Populasi dalam penelitian ini adalah perawat yang bekerja di RSUD dan Puskesmas di wilayah kabupaten Trenggalek. Sampel dalam penelitian ini berjumlah 60 responden. Responden diberikan kuesioner menggunakan format DASS (Depression, Anxiety and Stress Scale) untuk mengukur kecemasan, depresi dan tingkat stress perawat, dan diberikan kuesioner tentang mekanisme koping yang digunakan oleh perawat ketika mengalami kecemasan pada masa pandemic Covid-19.

\section{HASIL DAN PEMBAHASAN}

a. Gambaran karakteristik responden

Tabel 1: Distribusi frekwensi responden berdasarkan jenis kelamin, usia, pendidikan, dan lama bekerja (oktober 2020)

\begin{tabular}{|l|l|l|}
\hline \multicolumn{1}{|c|}{ Karakteristik } & \multicolumn{1}{|c|}{$\begin{array}{c}\text { Frekwensi } \\
\text { (F) }\end{array}$} & $\begin{array}{c}\text { Prosentase } \\
(\%)\end{array}$ \\
\hline Jenis kelamin & & \\
\hline Laki-laki & 22 & 37 \\
\hline Perempuan & 38 & 63 \\
\hline Umur & & \\
\hline $\mathbf{2 0 - 2 5}$ tahun & 4 & 6 \\
\hline $\mathbf{2 6 - 4 0}$ tahun & 31 & 52 \\
\hline
\end{tabular}




\begin{tabular}{|c|c|c|}
\hline $\begin{array}{l}\text { 41-50 tahun } \\
>50 \text { tahun }\end{array}$ & $\begin{array}{l}19 \\
6\end{array}$ & $\begin{array}{l}32 \\
10\end{array}$ \\
\hline \multicolumn{3}{|l|}{ Pendidikan } \\
\hline D3 Keperawatan & 47 & 78 \\
\hline S1 Keperawatan & 13 & 22 \\
\hline \multicolumn{3}{|l|}{ Lama Bekerja } \\
\hline$<1$ tahun & 2 & 3 \\
\hline 1-5 tahun & 6 & 10 \\
\hline 5-10 tahun & 12 & 20 \\
\hline 10-15 tahun & 13 & 22 \\
\hline 15-20 tahun & 18 & 30 \\
\hline$>20$ tahun & 9 & 15 \\
\hline
\end{tabular}

Sumber : Data primer, 2020

b. Tingkat Kecemasan Perawat

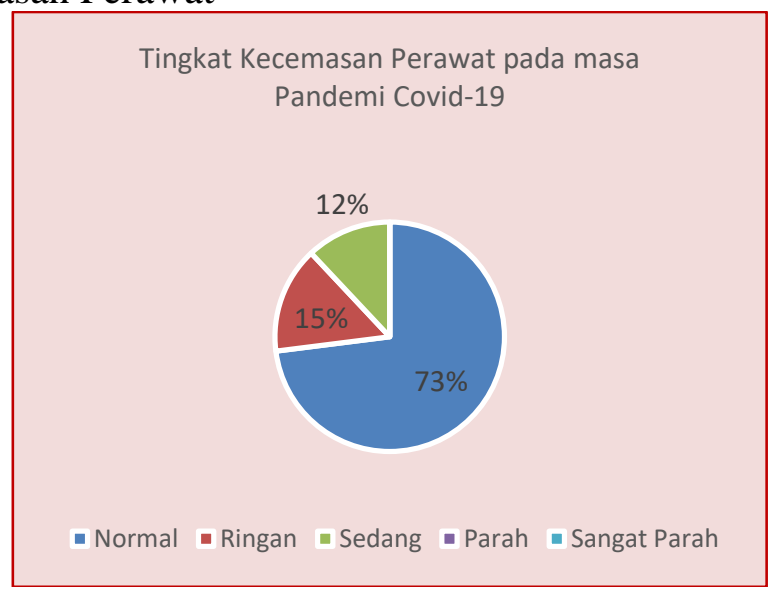

Sumber : Data primer, 2020

Gambar 1. Diagram Gambaran kecemasan perawat diwilayah Kabupaten Trenggalek menghadapi pandemic Covid-19

Berdasarkan diagram diatas dapat diperoleh informasi bahwa tingkat kecemasan perawat di wilayah kabupaten Trenggalek dalam menghadapai pandemi Covid-19 adalah sebesar $73 \%$ tidak mengalami kecemasan atau normal, $15 \%$ perawat mengalami kecemasan ringan dan $12 \%$ mengalami kecemasan sedang

c. Tingkat Depresi Perawat

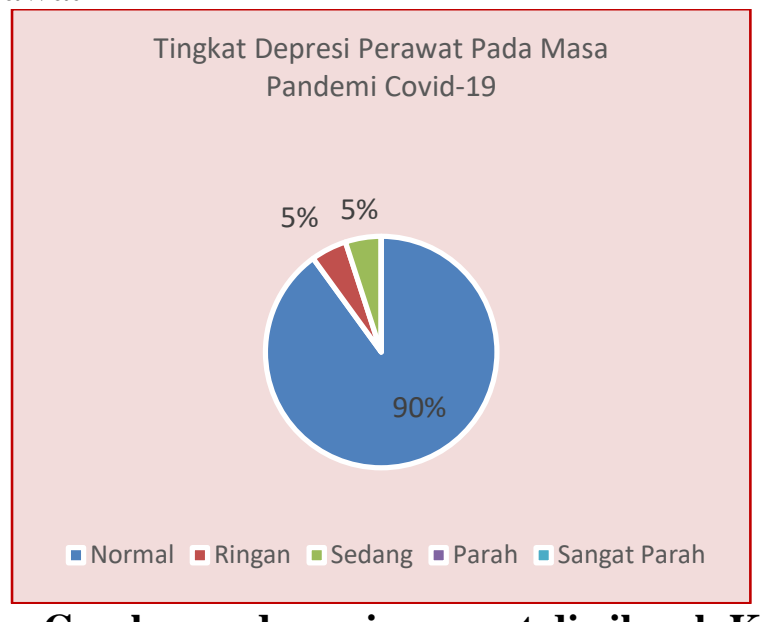

Gambar 2. Diagram Gambaran depresi perawat diwilayah Kabupaten Trenggalek menghadapi pandemic Covid-19 
Berdasarkan diagram diatas dapat diperoleh informasi bahwa tingkat depresi perawat di wilayah kabupaten Trenggalek dalam menghadapai pandemi Covid-19 adalah sebesar 90\% tidak mengalami depresi atau normal, 5\% perawat mengalami depresi ringan dan 5\% mengalami depresi sedang

d. Tingkat Stress Perawat

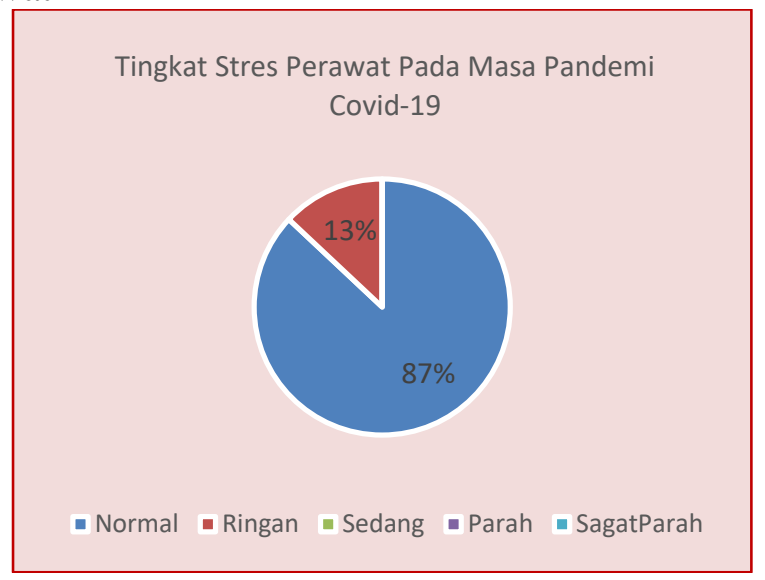

Sumber : Data primer, 2020

Gambar 3. Diagram Gambaran stress perawat diwilayah Kabupaten Trenggalek menghadapi pandemic Covid-19

Berdasarkan diagram diatas dapat diperoleh informasi bahwa tingkat stres perawat di wilayah kabupaten Trenggalek dalam menghadapai pandemi Covid-19 adalah sebesar 87\%\% tidak mengalami stres atau normal, dan hanya $13 \%$ perawat mengalami stres ringan.

e. Mekanisme Koping Perawat Adaptif Perawat

Mekanisme Koping Adaptif Perawat Pada Masa Pandemi

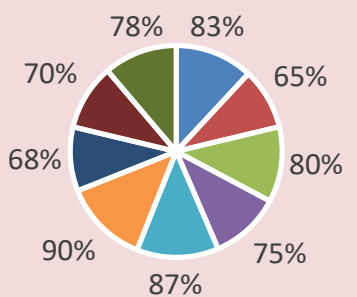

- Mencari Dukungan = Mencari informasi - Relaksasi

- Aktivitas fisik

- Berpikir optimis = Berdoa

- Makan

- Lebih Aktif Bekerja = Seminar Motivasi

Sumber : Data primer, 2020

Gambar 4. Diagram Gambaran mekanisme koping adaptif perawat diwilayah Kabupaten Trenggalek menghadapi pandemic Covid-19 
f. Mekanisme Koping Perawat Maladaptif Perawat

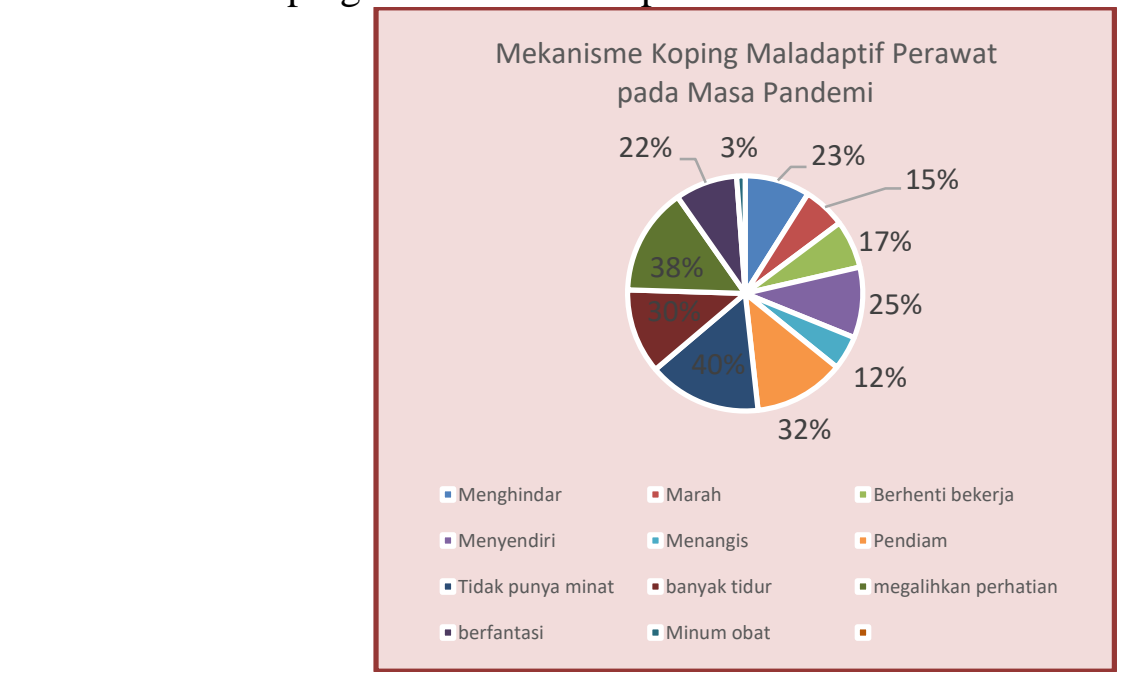

Gambar 5. Diagram Gambaran mekanisme koping maladaptif perawat diwilayah Kabupaten Trenggalek menghadapi pandemic Covid-19

\section{Pembahasan}

\section{a. Gambaran kecemasan perawat pada masa pandemic Covid-19}

Hasil penelitian menunjukkan bahwa gambaran kecemasan perawat di wilayah kabupaten Trenggalek pada masa pandemic ini adalah sebesar $73 \%$ tidak mengalami kecemasan, dan $15 \%$ perawat mengalami cemas ringan dan $12 \%$ mengalami cemas sedang.

Zhaorui, Liu, et al, 2020, Tujuan penelitian adalah untuk mengetahui status mental dari staff/tenaga kesehatan dan menemukan kunci untuk intervensi psikologis mereka. Peneitian berbasis survey dengan menggunakan SRQ-20 (self reporting quesioner-20), SAS (self rating anxiety scale), dan SDS (Self rating depression scale). Hasi penelitian menunjukkan bahawa 15,9\% mengalami distress, $16 \%$ mengalami gangguan cemas, dan $34.6 \%$ mengalami depresi. Hasil penelitian juga menunjukkan bahwa mereka yang memiliki resiko seperti anggota keluarga penderita, perawat, tenaga kesehatan yang berada di layanan kesehatan dan lain-lain memiliki gangguan psikologis atau gangguan mental.

Juhong Zhu, et al, 2020, melakukan penelitian untuk mengetahui prevalensi dan faktor yang mempengaruhi munculnya kecemasan dan depresi pada staff di unit pelayanan pertama pasien. Hasil penelitian menunjukkan prevalensi kecemasan dan depresi bagi dokter adalah $11,4 \%$ dan $45,5 \%$. Prevalensi kecemasan dan depresi pada perawat masing-masing adalah $27,9 \%$ dan $43 \%$.

Long Huang, et al., 2020, melakulan penelitian tentang Emotional responses and coping strategies of nurses and nursing college students during covid-19 outbreak. Penelitian ini dilakukan dengan menggunakan kuesioner online pada 1-9 februari 2020. Tujuan penelitian ini adalah untuk mengetahui respon emosional dan strategi koping perawat dan mahasiswa perawat. Instrumen yang digunakan adalah dengan menggunakan Brief COPE dan skala respon emosional. Hasil dari penelitian ini adalah pasrtisipan perempuan mempunyai tingkat kecemasan berat dari laki-laki. Partisipant yang tinggal di daerah perkotaan memiliki kecemasan yang lebih jika dibandingkan dengan partisipan dari pedesaan. Sedangkan mekanisme koping yang digunakan oleh partisipant dalam menghadapi wabah Covid-19, dari hasil penelitian menunjukkan bahwa merekka mereka menggunakan strategi "kemarahan, ketakutan dan kesedihan"

Analisis yang dilakukan terhadap hasil kuesioner yang diberikan pada responden, jika di analisis berdasarkan karakteristik responden, maka akan ditemukan beberapa hal sebagai berikut: 
a. $60 \%$ responden yang mengalami kecemasan berjenis kelamin laki-laki, dengan usia lebih dari 40 tahun. Hal ini dimungkinkan laki-laki sebagai kepala keluarga merasa cemas jika mengalami sakit dan tidak bisa bekerja

b. Responden yang mengalami kecemasan paling banyak dari RSUD dan dari puskesmas dengan riwayat kasus suspek Covid-19 banyak. Perawat pada ruang instalasi gawat darurat memiliki resiko lebih tinggi untuk terpapar dengan pasien Covid-19, sehingga kecemasan perawat lebih besar. Begitu juga dengan perawat yang berada pada wilayah dengan status pasien terkonfirmasi terbanyak, memiliki peluang untuk terpapar dengan pasien, sehingga kecemasan meningkat

c. Responden yang mengalami kecemasan berasal dari puskesmas dengan riwayat salah satu karyawan mengalami positif Covid-19, dan puskesmas dilakukan lockdown selama 1 minggu. Munculnya kasus positif Covid-19 pada staff dalam 1 lingkup ruang kerja akan meningkatkan respon cemas muncul pada staff perawat yang lain

\section{b. Gambaran depresi perawat pada masa pandemic Covid-19}

Hasil penelitian menunjukkan bahwa gambaran kecemasan perawat di wilayah kabupaten Trenggalek pada masa pandemic ini adalah sebesar 94\% tidak mengalami depresi, dan $6 \%$ perawat mengalami depresi ringan dan depresi sedang

An Ying, et al., 2020, melakukan penelitian tentang prevalensi depresi dan pengaruhnya terhadap kualitas hidup perawat di departemen emergensi selama pandemic Covid-19. Penelitian dilakukan dengan metode cross sectional berbasis survey online. Depresi dan kualitas hidup diukur menggunakan 9 item Patient Health Questionnaire dan WHO Qualityof Life Questionnaire-Brief version. Hasil penelitian menunjukkan bahwa 43,61\% perawat yang bekerja di departemen emergency mengalami depresi, dan kemudian depresi berpengaruh terhadap kualitas hidup perawat. Dari penelitian ini peneliti memberikan saran pada layanan kesehatan untuk menyediakan layanan pengobatan untuk mengatasi depresi terutama perawat yang bekerja di departemen emergency.

Roberts. N, et al, 2020 melakukan penelitian tentang tingkat kemampuan beradaptasi, tingkat kecemasan, depresi perawat yang bekerja pada klinik paru selama pandemic Covid-19. Penelitian ini merupakan penelitian studi ekplorasi tentang pengalaman perawat yang bekerja di klinik paru selama pandemic Covid-19. Survey didistribusikan pada perawat paru, dimana survey berisi kuesioner tentang tingkat kemampuan beradaptasi, tingkat kecemasan (GAD7) dan depresi (PHQ9). Dari 255 responden yang berpartisipasi dalam surve ini, didapatkan hasil $21 \%$ mengalami gejala kecemasan sedang dan berat. $17,2 \%$ responden mengalami depresi dan $18 \%$ mempunyai score tingkat kemampuan adaptasi yang rendah. Analisis regresi yang dilakukan menunjukkan bahwa variable kecemasan dan depresi, usia dan lama bekerja mempunyai hubungan yang signifikan. Perawat ang berusia relative lebih muda dengan pengalaman bekerja yang sedikit mempunyai tingkat kecemasan dan depresi yang berat, juga mempunyai kemampuan adaptasi yang rendah.

Zheng, R., et al, 2020 melakukan penelitian tentang prevalensi dan factor yang berhubungan dengan depresi dan kecemasan perawat selama pandei Covid-19. Tujuan penelitian adalah untuk mengetahui pengaruh Covid-19 terhadap kesehatan mental perawat, dan mengetahui prevalensi kecemasan dan dan depresi perawat di China selama masa pandemic Covid-19. Metode yang digunakan adalah cross sectional dengan menggunakan instrument $A$ self-reported questionnaire combining depression and anxiety scale, partisipan berjumlah 3228 perawat. Hasil penelitian menunjukkan bahwa bahwa sebanyak $34,3 \%$ perawat mengalami depresi, dan 18,1 \% mengalami kecemasan. Prevalensi kecemasan da depresi relative sama antara perawat yang bekerja pada wilayah resiko tinggi Covid-19 maupun yang resiko rendah. dengan hasil ini dapat disimpulkan bahwa perawat mengalami gangguan mental selama pandemic Covid-19. Dengan hasil penelitian ini, peneliti memberikan saran agar tempat pelayanan kesehatan atau rumah sakit memberikan program terapi kesehatan jiwa dengan 
berfokus pada kenyamanan bekerja dan dukungan keluarga untuk memperbaiki kesehatan jiwa perawat.

Hasil analisis terhadap hasil penelitian, responden yang mengalami depresi lebih berat adalah laki-laki dengan usia lebih dari 45 tahun. Informasi tentang Covid dan factor resiko terkena Covid-19 kemungkinan menjadi penyebab hal ini terjadi. Responden dengan usia yang lebih banyak memiliki tingkatan depresi lebih dibandingkan dengan responden yang berusia lebih muda.

\section{c. Gambaran stress perawat pada masa pandemic Covid-19}

Hasil penelitian menunjukkan bahwa gambaran kecemasan perawat di wilayah kabupaten Trenggalek pada masa pandemic ini adalah sebesar $87 \%$ tidak mengalami stress psikologis, dan $13 \%$ perawat mengalami gangguan stress psikologis.

Almazan, J., et al., 2019, melakukan penelitian tentang ekplorasi stress kerja perawat di ruang pelayanan akut. Tujuan dari penelitian adalah untuk mengkaji stress kerja perawat dan factor-faktor yang berhubungan antara stress kerja perawat dan status demografi. Metode yang digunakan dalam penelitian ini adalah deskriptif cross sectional yang dilakukan terhadap 178 perawat. Hasil penelitian menunjukkan bahwa perawat mengalami stress skala sedang pada lingkungan kerja. Factor asal negara perawat merupakan menjadi factor predisposisi yang signifikan meningkatnya level stress perawat. Perawat India mengalami tingkat stress yang paling tinggi yang dihubungkan dengan perawat dari negara lain. Jam kerja perawat setiap minggu menjadi factor penyebab lain munculnya stress. Peneliti menyimpulkan bahwa stress perawat dapat terjadi dilingkungan kerja, pertama jam kerja perawat merupakan factor yang secara langsung berhubungan dengan tingkat stress perawat. Kedua, adalah factor demografik asal perawat yang bekerja pada lingkungan kerja tersebut. Peneliti memberikan saran bahwa layanan kesehatan atau rumah sakit harus mempunyai aturan yang bertujuan untuk mengurangi stress perawat, melakukan promosi perbaikan pelayanan kesehatan dan tugas yang jelas dalam tindakan.

Tayyib, N., et al .,2020, melakukan penelitian tentang pengukuran tingkat stress da ketakutan perawat selamapandemik Covid-19. Peneltian ini merupakan study cross sectional yang dilakukan pada seluruh perawat registered nurses yang bekerja pada pasien Covid-19. Partisipan mengisi kuesioner yang berisi tentang data demografi, stress kerja yan berhubungan dengan Covid-19, dan ketakutan akan infeksi tersebut. Data dianalisis dengan deskriptif korelatife dan multiple regresii. Hasil penelitian adalah dari 314 partisipan yang dilakukan surve menunjukkan bahwa mereka mengalami tingkat kecemasan dan tingkat stress yang tinggi selama masa pandemik Covid-19. Ketakutan mereka berhubungan dengan keamanan mereka dalam bekerja dan ketakutan akan keluarga mereka. Beberapa factor yang menjadi predisposisi seperti media sosisal, terpapar pada pasien Covid-19, dan tanggung jawab untuk merawat pasien dengan Covid-19. Kesimpulan peneliti adalah perawat mengalami tingkat stress dan ketakutan yang tinggi ketika merawat pasien dengan Covid-19, hal ini dapat berefek pada status psikologis perawat dan kualitas pelayanan pada pasien.

Melihat hasil penelitian ini ada beberapa hal yang kemungkinan bisa berpengaruh terhadap hasil dimana perawat tidak mengalami stress selama masa pandemik Covid-19. Dukungan keluarga, dukungan teman, lingkungan social bisa menjadi factor yang dapat menurunkan tingkat stress perawat. Selain itu factor angka kejadian penderita Covid-19 pada suatu wilayah tertentu juga berperan terhadap tingkat stress perawat yang bekerja pada layanan kesehatan, termasuk didalamnya adalah keijakan pemerintah setempat tentang upaya penanggulangan pandemic, kebijakan rumah sakit dan layanan kesehatan lain dalam menangani pasien Covid-19 dapat berperan terhadap tingkat stress perawat selama masa pandemic Covid19. Pengalaman bekerja pada layanan kesehatan juga ikut berkontribusi terhadap hasil penelitian, dimana perawat yang bekerja dalam waktu yang lama dimungkinkan memiliki mekanisme koping yang bagus dalam menghadapai situais yang menimbulkan stress.

Perawat yang bekerja pada wilayah dengan peningkatan kasus suspek Covid-19, cenderung memiliki tingkat stress yang lebih daripada perawat yang bekerja pada wilayah 
dengan jumlah kasus yang rendah. hal ini dikarenakan perawat harus mempersiapkan diri untuk menerima pasien dengan Covid setiap saat, dan harus mempersiapkan coping ketika pasien datang pada mereka dengan ataupun tanpa Covid-19. Perawat yang bekerja di ruang istalasi gawat darurat juga mempunyai tingkat stress yang lebih tinggi dibandingkan dengan perawat yang bekerja di ruang perawatan. Perawat pada ruang-ruang tersebut cenderung mempunyai resiko terpapar lebih tinggi daripada perawat yang berada diruang perawatan umum, pasien yang datang dengan membawa resiko kemungkinan terkena Covid-19 baik dengan gejala yang terlihat atau tidak, selain itu pasien yang sering didapatkan tidak memberikan informasi secara jujur pada perawat menjadi factor predisposisi munculnya stress pada perawat.

Factor lain yang dapat menjadi penyebab stress dan kecemasan perawat pada masa pandemic Covid-19 adalah ketidaksediaan persiapan layanan kesehatan untuk menerima wabah penyakit ini. Perawat belum mempersiapkan mekanisme koping yang tepat untuk menerima stressor yang muncul akibat wabah Covid-19 ini. Perawat cenderung menerima informasi yang sangat banyak/sangat beragamm tentang Covid-19 dalam waktu yang singkat, dalam waktu yang bersamaan dan dari berbagai sumber. Hal ini bisa menjadi sesuatu yang membingungkan bagi perawat dalam menyikapi informasi-informasi tersebut, bukan menjadi sumber koping yang adaptif tetapi semakin meningkatkan stress perawat.

Stress pada perawat selama masa pandemic Covid-19 dapat juga terjadi karena adanya konflik nilai professional perawat. Perawat yang memiliki mekanisme koping yang lemah atau maladaptive akan berpikir untuk meninggalkan tanggung jawab sebagai perawat, mengundurkan diri dari rumahsakit tempat bekerja, tidak mau melakukan tanggung jawabnya melayani pasien, atau menghindari pasien yang terkonfirmasi positif atau suspek mengalami Covid-19. Hal-hal ini akan menjadi sumber stressor perawat lain yang, yang memungkinkan perawat lain akan mengikuti jejak perawat tersebut ketika mekanisme koping adaptif sudah sudah tidak dapat mentolerir diri lagi. Konflik professional juga dapat menyebabkan terjadinya peningkatan beban kerja perawat yang lain ketika ada perawat yang melakukan resign atau melakukan mekanisme koping menghindari pasien.

Stressor perawat dapat juga berasal dari konflik peran antara keluarga dan pekerjaan. Selama masa pendemik Covid-19 telah diberlakukan kebijakan nasional berupa bekerja dari rumah, belajar dari rumah. Kebijakan ini menimbulkan konflik peran bagi perawat yang harus tetap bekerja di layanan kesehatan, sementara mereka mempunyai tanggung jawab untuk mendidik anak-anak merka ketika melakukan proses pembelajaran di rumah. Konflik lain muncul ketika mereka harus mengambil keputusan untuk mendatang guru bagi anak-anak mereka, muncul stressor bagaimana penyediaan anggaran untuk guru, bagaimana memastikan bahwa anaknya mampu belajar dengan orang yang baru, memastikan bahwa anaknya akan aman dari resiko penularan Covid dari orang yang baru.

\section{d. Mekanisme koping perawat pada masa pandemic Covid-19}

Hasil penelitian menunjukkan bahwa perawat di wilayah kabupaten Trenggalek lebih banyak menggunakan mekanisme koping adaptif, tetapi ada juga yang menggunakan mekanisme koping maladaptive untuk mengatasi stressor dalam menjalanakan tugas pada masa pandemic Covid-19. Meknaisme koping yang paling banyak digunakan adalah berdoa, mencari dukungan/ support dari orang-orang terdekat, teman, keluarga ketika merasakan cemas, melakukan teknik relaksasi dan melakukan aktivitas fisik ringan ketika merasakan kejenuhan, kelelahan dan stress dalam menjalankan tugas pada masa pandemic Covid-19.

Meskipun demikian responden juga ada yang menggunakan mekanisme koping maladptif ketika mengalami kecemasan, stress dalam menjalankan tugas. Mekanisme koping yang digunakan seperti tidak berminat untuk melakukan tanggung jawab ketika pasien tidak melakukan protocol kesehatan, selain itu perawat suka menyendiri, sedih, marah mennangis, berubah menjadi pendiam dan melakukan hal-hal lain selain tugasnya seperti bermain social media, melihat drama dan lain-lain.

Roberts. N, et al, 2020 melakukan penelitian tentang tingkat kemampuan beradaptasi, tingkat kecemasan, depresi perawat yang bekerja pada klinik paru selama pandemic Covid-19. 
Hasil penelitian menyimpulkan bahwa pada masa pandemic Covid-19 mekannisme koping yang dibutuhkan oleh perawat adalah dukungan psikologis untuk meingkatkankemampuan bertahan dari perawat dalam menghadapi masa pandemic Covid-19. Dukungan dapat dilakukan melalui telepo, internet, media social, dukungan dalam kelompok social serta memberikan informasi-informasi yang dibutuhkan oleh perawat.

$\mathrm{Xu}$, Hui, et al, 2019, melakukan penelitian tentang stressor dan mekanisme koping perawat di departemen emergency dengan tujuan untuk mendeskripsikan persepsi perawat pada departemen emergency terhadap lingkungan kerja. Metode penelitian yang digunakan adalah studi cross sectional. Dengan descriptive dan comparative analisys. Surve yang dilakukan adalah mengeksplorasi tentang stressor lingkungan keja, mekanisme koping yang digunakan, dan persepsi pada ligkungan kerja. Hasil penelitian menunjukkan bahwa perawat mempunyai beban kerja yang tinggi, realisasi diri yang sedang, dan tingkat konflik dan ketakutan yang rendah. Perawat mengalami beban kerja yang berat, memliki skill/ ketrampilan yang rendah dan tingkat stess yang tinggi setiap hari. Kejadian setiap hari seperti kematian dan kasus penganiayaan seksual pada anak semakin meningkatkan stress. Strategi koping yang digunakan oleh perawat antara lain $90 \%$ perawat mencoba untuk hidup senormal mungkin, serta mengingat dan mencari cara yang berbeda untuk mengatasi situasi yang dialami. Peneliti menyimpulkan bahwa dampak yang bervariasi dapat terjadi dalam jangka waktu yang lama, dengan pengalaman yang terbatas, stressor yang termodifikasi dapat menjadi peluang untuk menambahkan persepsi mereka terhadap lingkungan.

Long Huang, et al., 2020, menunjukan hasil penelitian bahwa mekanisme koping yang digunakan oleh perawat sebagai partisipan dalam penelitiannya dalam menghadapi wabah Covid-19. Hasil penelitian menunjukkan bahwa pada masa pandemic Covid-19 perawat lebih banyak menggunakan mekanisme koping dengan strategi "kemarahan, ketakutan dan kesedihan" mekanisme koping maladptif ini paling banyak dilakukan sebagai bentuk pertahanan diri terhadap stressor dalam menghadapi tanggung jawab sebagai perawat pada masa pandemic Covid-29.

Naeim M, 2020 dalam penelitiannya menunjukkan bahwa mekanisme koping yang digunakan oleh perawat untuk mengurangi kecemasan dan depresi perawat dalam menghadapi pandemic Covid-19 adalah :

a. Melakukan latihan/olahraga ringan, berjalan-jalan di luar ruangan dan melakukan latihan nafas dalam

b. Memperkuar kerjasama dalam tim dan saling memberikan dukungan satu dengan yang lain

c. Mengungkapkan apa yang dirasakan atausetiap keluhan yang dirasakan dengan orang lain

d. Berpikir positif dan berikan semangat positif pada orang lain

e. Mengurangi penggunaan jaringan virtual

f. Berfokus pada cara yang dapat mengontrol diri dalam menghadapi krisis. Tidak berfokus pada berbagai cara tetapi tidak bisa mengontrol diri

g. Membuat jadwal untuk bertemu dengan teman dan keluarga

h. Jika merasakan tekanan yangmengarah pada kecemasan dan depresi, melakukan kunjungan pada psikolog dan psikiater untuk beberapa hari

i. Hindari diri dari gangguan tidur

j. Melalukan perbaikan dan perencanaan nutrisi yang lebih baik

k. Tingkatkan semangat dan harapan pada diri dan orang-orang di sekitar kita

1. Menggunakan pendekatan "terapi bahagia" seperti humor, tertawa

m. Hindari stress diri dan orang lain dari berita-berita yang mengerikan

Rosyanti, L, 2020, menyebutkan pentingnya mekanisme koping pada perawat seperti mekanisme koping menncari dukungan dari orang-orang terdekat, keluarga agar perawat dan tenaga kesehatan mempunyai kekuatan fisik dan mental dalam mennjalankan tugas selama pandemic Covid-19. Factor resiko seperti perasaan tidak didukung, kekawatiran tentang kesehatan pribadi, takut membawa infeksi dan menularkannya pada anggota keluarga di rumah, takut diisolasi, stigmatisasi social, beban kerja yang berlebih serta perasaan tidak aman ketika 
memberikan layanan perawatan pada pasien Covid-19 dapat menjadi dampak yang tidak baik pada tenaga kesehatan termasuk perawat.

Utari R, dkk, 2020, menyebutkan pentingnya dukungan social dan kecerdasan emosional untuk mengatasi stress pada masa pandemik Covid-19. Semakin tinggi dukungan social maka semakin rendah stress yang dirasakan, jika semakin tinggi kecerdasan emosional maka akan semakin rendah stress yang dirasakan, begitupun sebaliknya. Dukungan social menyumbang lebih besar dalam mengatasi stress dibandingkan dengan kecerdasan emosional.

Forozeiya, D,et al. 2020, dalam penelitiannya bahwa dengan membangun strategi koping seperti melihat dukungan social media, maka perawat dapat bergerak, memiliki kekuatan yang penuh dalam melakukan perawatan pada pasien dan keluarga pasien dengan penyakit kritis. Ketika mekanisme koping tidak tersedia, maka perawat beresiko untuk menjadi tidak menggunakan moral dalam melakukan praktik pada pasien.

\section{KESIMPULAN}

Perawat diwilayah kabupaten Trenggalek mengalami mengalami kecemasan ringan sedang, mengalami depresi ringan - sedang dan mengalami stress ringan pada masa pandemic Covid-19. Perawat menggunakan mekanisme koping adaptif seperti mencari dukungan, melakukan relaksasi, berdoa dan juga melakukan mekanisme koping maladaptive seperti menyendiri, pendiam, menangis, marah ketika mengalami stress dan kecemasan pada masa pandemic Covid-19. Dengan hasil ini diharapkan layanan kesehatan menyediakan fasilitas layanan konseling pada tenaga kesehatan yang menjalankan tugas pada masa pandemic Covid19 ini, untuk mencegah stress, kecemasan dan depresi menjadi dampak yang buruk terhadap tenaga kesehatan

\section{DAFTAR PUSTAKA}

Almazan, J, et al. 2019. Exploring Nurses Work-Related Stress In An Acute Carehospitalin KSA. Journal of Taibah University Medical Sciences (2020). https://doi.org/10.1016/j.jtumed.2019.04.006

An Ying, et al. 2020. Prevalence Of Depression And Its Impact On Quality Of Life Among Frontline Nurses In Emergency Departments During The COVID-19 Outbreak. https://doi.org/10.1016/j.jad.2020.06.047 : Elsevier

Dinah,dkk. 2020. Gambaran Tingkat Kecemasan Perawat Saat pandemic Covid-19di Negara Berkembang dan Negara Maju : A literature review

Forozeiya, D, et al. 2020. Coping With Moral Distress- The Experinces Of Intensive Care Nurses: A Interpretiew Descriptive Study. https://doi.org/10.1016/j.iccn.2019.03.002 : Elsevier

Huang, Long, et al.2020. Emotional respons and coping strategis of nurses and nursing college students during COVID-19 outbreak. China

Huang, Yeen, and Zhao Ning. 2020. Generalized anxiety disorder, depressive symptoms and sleep quality during COVID-19 outbreak in China: a web-based cross-sectional survey. Elsevier B.V. http://doi.org/10.1016/j.psychres.2020.112954

Keliat, Budi A.dan Pasaribu J. 2013. Prinsip dan Praktik Keperawatan Kesehatan Jiwa Stuart, 1 st Indonesia edition. Elsevier

Komite Koordinasi Pendidikan RSUD dr.Soetomo. 2020. Buku Panduan Perlindungan Bagi PPDS Dalam Perawatan Pasien Selama Pandemi Covid-19. Surabaya : FKUA

Liu, Zhaorui et al. 2020. Mental Health status of doctors and nurses during COVID-19 epidemic in China. China. The Lancet-D-20-02983.

M. Naeim, Strategies to reduce the anxiety and depression of nurses in the special wards of COVID-19, Archives of Psychiatric Nursing(2020), https://doi.org/10.1016/j.apnu.2020.07.028

National Safety Council. 2004. Manajemen Stres; Alih bahasa oleh Palupi Widyastuti; Editor bahasa Indonesia Devi Yulianti. Jakarta : EGC 
Nursalam. 2014. Metodologi Peneitian Ilmu Keperawatan. Jakarta : Salemba Medika

Pappa, Sofia et al, 2020. Prevalence of Depression, anxiety, and insomnia among healthcare workes during the COVID-19 pandemic : A systematic review and meta-analysis. Elsevier Inc. http://doi.org/10.1016/j.bbi.2020.05.026

Pardede J,dkk.2020. Optimalisasi Koping Perawat Mengatasi Kecemasan Pada Masa Pandemi Covid-19 Di Era New Normal. Jurnal Peduli Masyarakat Volume 2 Nomor 3, September

E-ISSN 2721-9747; P-ISSN

2020

Http://Jurnal.Globalhealthsciencegroup.Com/Index.Php/JPM

Robert, $\mathrm{N}$, et al. Levels of resilience, anxiety and depression in nurses working in respiratory clinical areas during the COVID pandemic. Https://doi.org/10.1026/j.rmed.2020.106219 : Elsevier

Rosyanti, L dan Hadi, I,. 2020. Dampak Psikologis dalam Memberikan Perawatan dan Layanan Kesehatan Pasien Covid-19 Pada Tenaga Profesional Kesehatan

Rusman. 2009. Stres, Koping dan Adaptasi.Teori dan pohon masalah keperawatan edisi pertama. Jakarta : Sagung Seto

Shanafelt, Tait et al. 2020. Understanding and Addressing Sources of Anxiety Among Health Care Professional During the COVID-19 Pandemic. California. American Medical Association. http://jamanetwork.com/on07/15/2020

Soedarsono. 2020. Webinar tentang Diagnosis dan Tatalaksana Coronavirus Disease 2019 (COVID-19)

Soedarsono. 2020. Webinar tentang Tatalaksana COVID-19:

Pasien Rawat Jalan dan Rawat Inap

Sugiyono. 2010. Metode Penelitian Kuantitatif, Kualitatif dan R\&D. Bandung : Alfabeta

Tayyib, N,et al. 2020. Measuring The Extent Of Stress And Fear Amongregistered Nurses In KSA During The Covis-19 Outbreak. Journal of Taibah University Medical Sciences (2020) 15(5), 410e416

Utari R, dkk. 2020. Dukungan Sosial dan Kecerdasan Emosional (Emotional Quotient) dengan Stres di tengah Pandemi Covid-19 pada Masyarakat Cempaka Putih Barat, Jakarta Pusat.Jurnal IKRA-ITH Humaira Vol4 No3 bulan Novemer 2020

World Health Organization (WHO). 2020. Clinical Management of Covid-19 Interm Guidance.

Wu Dongmei, et al. 2020. Stressors of nurses in psychiatric hospitals during the COVID-19 outbreak. https://doi.org/10.1016/j.psychres.2020.112956 Elsevier

$\mathrm{Xu}, \mathrm{Hui}$, et al. 2020. stressor and coping strategis of emergency department nurses and doctor : A cross-sectional study. https://doi.org/10.1016/j.auec.2018.10.005:Elsevier0

Zheng, R, et al. 2020. Prevalence And Associated Factors Of Depression And Anxiety Among Nurses During The Outbreak Of COVID-19 In China: A Cross-Sectional Study. https://doi.org/10.1016/j.ijnurstu.2020.103809. Elsevier

Zhu, Juhong et al, 2020. Prevalence and Influence Factors of Anxiety and Depression Symptoms in the First - Line Medical Staff Fighting Againt COVID-19 in Gansu. Frontiers in Psychiatry. www.frontiersin.org 